\title{
Dekorasi dan Dramatika Tata Panggung Teater
}

\author{
Untung Tri Budi Antono* \\ Jurusan Teater, Fakultas Seni Pertunjukan, Institut Seni Indonesia Yogyakarta.
}

\begin{abstract}
Decoration and Dramatic of the Theatre Stage Setting. Pada awalnya tata panggung teater hanya berfungsi sebagai dekor permainan drama saja sampai dengan abad 18 di Eropa. Kemudian berkembang fungsi dan penataannya, yaitu juga sebagai lingkungan permainan yang mendukung dramatika peristiwa lakon. Dengan demikian, tata panggung sebagai latar ruang, waktu dan suasana adalah salah satu fenomena unsur visual dalam seni teater yang berada pada fungsi dekorasi dan dramatika.
\end{abstract}

Key words: decoration, dramatic, function

\section{Pendahuluan}

Sejak awal kemunculan drama panggung sampai abad 18 di Eropa, tata artistik panggung hanya berfungsi sebagai latar belakang permainan saja, bukan untuk menciptakan lingkungan peristiwa lakon sebagai pendukung dramatika (Antono, 2004: 287). Hal ini terjadi sebagai transformasi dari ritual menjadi pertunjukan yang sekuler dengan pola pengadegan yang linier. Pada periode ini latar belakang tata artistik panggung lebih berfungsi sebagai dekor yang menandakan tingkat sosial atau golongan di kalangan apa terjadinya peristiwa lakon. Dengan demikian dramatika tata panggung dan juga tata artistik yang lain hanya sekedar memberi imaji komunal, belum memberi imaji personal.

Pada masa itu pementasan drama diawali dengan mentransformasikan cerita-cerita mitos secara realistik di mana karakter mitologi diwujudkan sebagai human being. Kemudian dilanjutkan dengan Tragedi, Komedi dan Satir. Pada Abad Pertengahan drama Klasik digantikan dengan drama Liturgi Kristen. Sesudah itu, pada masa Renesans drama Klasik lahir kembali masih dengan tata panggung dekor hingga abad 18, meskipun sudah menggunakan panggung prosenium. Kemudian sesudah spirit Renesans mulai surut, sejak abad 18 tata panggung yang hanya sebagai dekor mulai ditinggalkan dan dikembangkan menjadi tata panggung dramatika.

\section{Tata Panggung Teater}

Sebagai pemahaman fungsi tata panggung, Padmodarmaya (1983: 80-83) menguraikan bahwa tata panggung permainan drama atau skeneri adalah merupakan bagian dari penampilan visi pengarang cerita dan sutradara. Dengan demikian unsur ruang, waktu dan suasana dalam cerita divisualkan pada pementasan dramanya.

Selanjutnya dikemukakan bahwa tata panggung realistis dirancang untuk memberi imaji suasana yang mendukung adegan realistis. Hasil rancangan itu merupakan perwujudan ide suatu tempat dalam cerita dengan menggunakan bentuk tiruan yang murni. Tujuannya agar penonton terstimulasi asosiasi emosionalnya terhadap tempat yang dikehendaki dalam cerita itu.

Untuk menciptakan tata panggung yang realistis, bukan berarti memindah bentuk dari alam secara lengkap. Penata panggung yang baik tidak akan menampilkan tata panggung yang sangat rinci dan teliti seperti gambar potret, karena akan merusak panggung dalam hubungannya dengan laku pemain. Hal ini bisa diartikan bahwa tata panggung yang detil akan mendominasi pentas, mengaburkan permainan para pemeran, atau dengan kata lain merusak tata pemeranan atau penyutradaraannya. Dengan demikian tata panggung realistik yang baik adalah yang mereduksi sebagian unsur-unsurnya menjadi unsur imajiner dan memvisualkan unsur-unsur

\footnotetext{
* Alamat korespondensi: Jurusan Teater ISI Yogyakarta. Jalan Parangtritis Km. 6,5 Sewon, Kotak Pos 1284 Yogyakarta. Telepon 0274-375380, HP: 0818276569, e-mail: untungtba@gmail.com
} 
yang bobot representasinya tinggi. Sistem ini menjadikan tata panggung yang sugestif-realistis, yaitu tata panggung yang sederhana namun memberi imaji latar peristiwa lakon yang lengkap.

Masing-masing bentuk unsur dalam tata panggung adalah simbol representasi dari bentuk lain yang pernah terekam dalam ingatan penonton. Bentuk dalam ingatan penonton yang mengacu pada obyek ruang, waktu dan suasana yang sebenarnya, direduksi menjadi bentuk yang simpel dengan menghadirkan dan menyusun unsur-unsur yang representatif saja.

Pada tata panggung non-realistik, unsurunsurnya tidak merepresentasikan ruang, waktu dan suasana yang realistis, tetapi merupakan bagian dari komposisi gerak laku atau dramatika permainan. Unsur tata panggung bukan hanya sekedar untuk direspon oleh pemain, tetapi menjadi bagian yang dimainkan.

Pada tata panggung formal, unsur-unsurnya hanya merupakan tempat permainan dan dekor. Setiap unsur tata panggung hanya dirancang untuk mengoptimalisasi keindahan pertunjukan, mempertinggi daya tarik tontonan. Tata panggung ini sering dipakai untuk drama tari yang tidak mementingkan dukungan dramatika ruang, waktu dan suasana.

Pada saat sebuah tata panggung telah siap mengantarkan atmosfir teatrikal kepada para penonton, seperti juga suatu ruangan dalam kehidupan, seorang penata panggung harus menembus wilayah ruang lebih jauh daripada seorang dekorator, karena teater bukanlah kehidupan yang sebenarnya. Teater justru menggambarkan kehidupan dengan dimensi yang lebih dalam sesuai dengan arti kehidupan itu sendiri (Jones dalam Wilson dalam Christiawan, 1992: 10). Dengan demikian tata panggung bukan hanya sekedar dekor, tetapi memiliki makna ruang kehidupan yang tidak biasa, khusus, unik dan hakiki. Unsur-unsur tata panggung harus merupakan tanda-tanda terpilih yang mendukung efektivitas dramatika lakon sebagai cerita peristiwa kehidupan.

Perancang tata panggung, seperti pekerja teater yang lain, juga harus memahami naskah drama. Perancang tata panggung menganalisis naskah drama pada beberapa hal antara lain indikasi periode, tempat, faktor sosial dan ekonomi, juga indikasi tipe dan gaya, yaitu tragedi, melodrama, komedi, simbolisme, ekspresionisme, realisme dan sebagainya (Brockett, 1964: 426-427). Dengan demikian unsur-unsur tata panggung harus menandakan ruang, waktu, suasana, kondisi sosial dan ekonomi, serta macam dan gaya permainan sesuai dengan tuntutan lakon.

Dalam mempelajari naskah, perancang tata panggung akan fokus pada hal-hal yang memberi petunjuk tentang tuntutan skenik dan gaya visual. Selama proses perancangan tata panggung, perancang mengumpulkan informasi dari berbagai hal tentang ruang yaitu jumlah tempat, jenis tempat (penjara, ruang tamu, taman dan lain-lain). Juga ruang yang dibutuhkan untuk aksi di setiap adegan, penetapan lokasi masuk keluar, penempatan perabotan rumah, penentuan tempat berjalan, peletakan level (kotak dataran) dan lainlain yang diperlukan untuk aksi di setiap adegan. Demikian juga periode, letak geografis tempat, kondisi sosial-ekonomi, dan berbagai faktor lain yang mempengaruhi pemandangan (Brockett, 1988: 340). Berbagai hal yang menginformasikan ruang adalah tanda-tanda sastrawi dalam naskah, yang harus diinterpretasikan dan kemudian diwujudkan menjadi tata panggung sebagai tanda visual yang fungsional untuk akting, dan menghasilkan tata panggung permainan yang merepresentasikan ruang, waktu dan suasana dalam cerita.

Desain tata panggung menjadi lebih dari sekedar dekorasi untuk menutupi belakang panggung yang kosong, atau menunjukkan waktu dan tempat. Ia menciptakan suasana, gaya dan metafora yang merupakan bagian organik ruang dan waktu dalam perkembangan irama permainan. Tata panggung harus membentuk aksi, memperkuat makna dan menggerakkan permainan sebagai ketentuannya (Kernodle, 1967: 428). Oleh sebab itu tata panggung harus menghadirkan dan menyusun unsur-unsur yang mendukung dan mengoptimalkan dramatika peristiwa lakon.

\section{Tata Panggung Teater di Indonesia}

Ketika bangsa Eropa datang ke Indonesia, terutama pada masa penjajahan Belanda, 'dibawalah' panggung prosenium ke Indonesia dengan tata panggung dekornya. Panggung prosenium dengan tata panggung dekor ini kemudian merubah tradisi tempat pertunjukan di Indonesia yang sebelumnya berbentuk arena (Antono, 2007: 57), yaitu halaman rumah, pendopo dan tempat-tempat terbuka 
lainnya yang tidak memungkinkan untuk diberi dekor. Tata panggung dekor dalam panggung prosenium ini kemudian lebih melekat pada drama atau teater tradisional seperti wayang orang, ketoprak, ludruk dan sebagainya dalam waktu yang lama hingga sekarang. Melekatnya tata panggung dekor pada drama tradisional rupanya sangat berkaitan dengan pola pengadegan yang linier seperti pada drama Klasik di Barat. Pola pengadegan linier bisa dikatakan semi dramatika, karena pemeran lebih bertindak sebagai 'pelaku tokoh' daripada 'penghayat tokoh'. Pelaku tokoh hanya berperan dengan raganya, sedangkan penghayat tokoh lebih berperan dengan jiwanya.

Ketika drama modern muncul di Indonesia, tidak serta-merta tata panggung dramatika hadir bersamanya. Hal ini terjadi karena berbagai faktor antara lain: (1) Drama modern di Indonesia masih dalam bayang-bayang hegemoni tradisi lesan atau tutur yang tidak mementingkan visualisasi ruang. Dalam drama tradisional, visualisasi ruang menjadi penting karena termotivasi oleh ikonisitas yang tinggi dari unsur-unsur ruang yang dihadirkan, misalnya bangunan kerajaan, candi dan sebagainya; (2) Keterbatasan pemahaman teknis perancangan transformasi dari gagasan ruang dalam naskah cerita sebagai citra menjadi gagasan ruang dalam panggung yang dibendakan sebagai wimba; dan (3) Jumlah panggung prosenium permanen yang sedikit membuat kurang memberi peluang munculnya para penata panggung yang kreatif dan profesional. Hal ini bisa dibandingkan dengan di Italia pada masa Renesans.

Pada masa sekarang wawasan dan pemahaman tentang tata panggung memang sudah meningkat, dengan diikuti munculnya banyak penata panggung muda. Namun demikian masih banyak hal yang perlu dikritisi.

\section{Dekorasi Tata Panggung Teater}

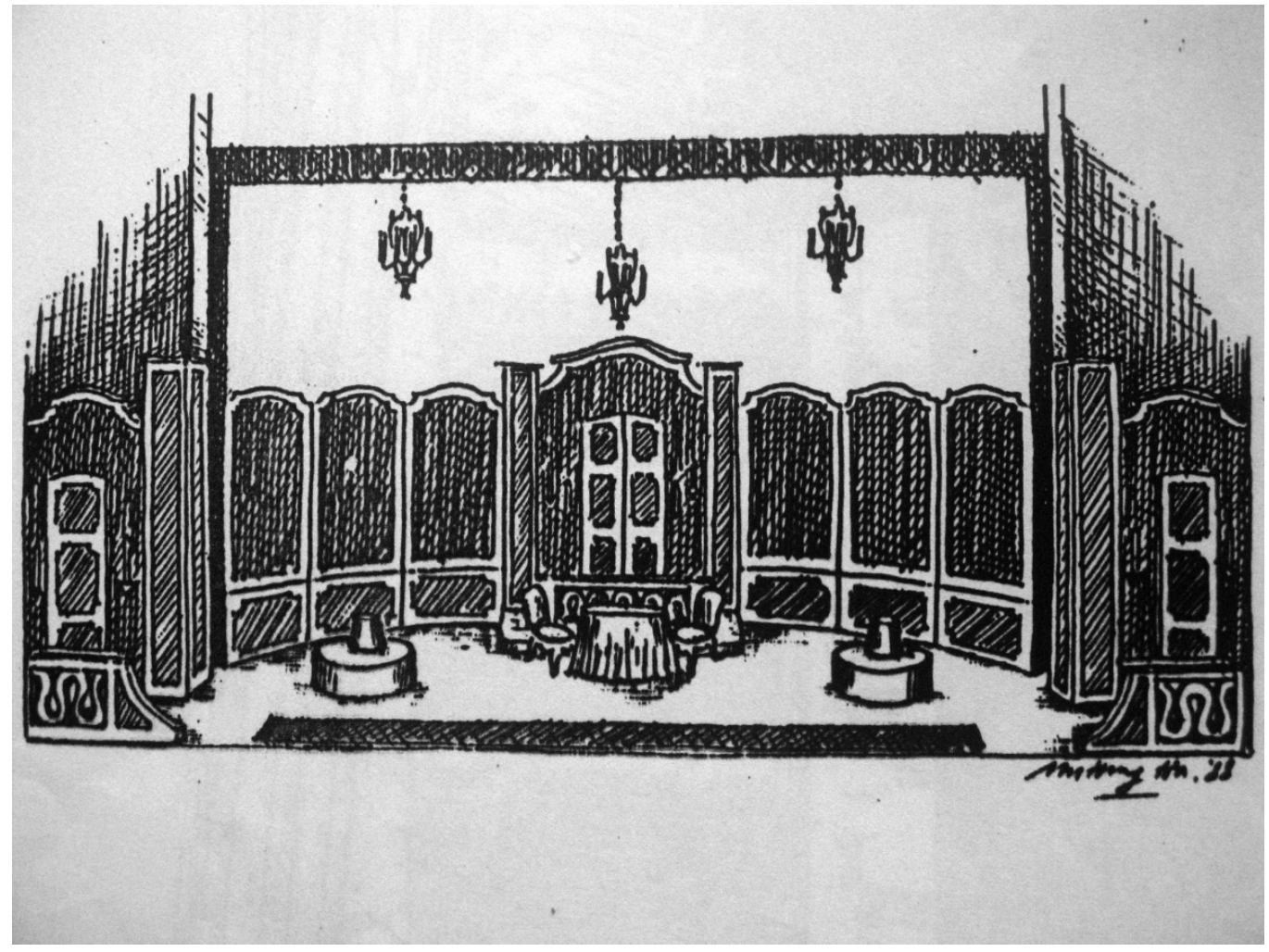

Reproduksi sketsa tata panggung dekoratif Tartuffe Molière karya Charles Watson oleh Untung T.B.A. ( Brockett, 1964: 428)

Dekor yang melengkapi pementasan drama pada awal kemunculannya menjadi bagian penting bagi dramatika lakon. Dekor mempunyai dua fungsi yaitu: (1) Untuk menciptakan kemeriahan dan kemewahan sebagai bagian dari attraction of spectacle dan (2) Sebagai tanda majemuk yang memberi imaji golongan atau kalangan masyarakat di mana terjadinya peristiwa lakon. 
Penggunaan dekor ini rupanya sejalan dengan pola pengadegan yang masih linier dan statis. Mode ini masih terus berlangsung pada drama tradisional di Indonesia yang didasari pemahaman terhadap cerita-cerita lakon yang dibawakannya sebagai mitologi dengan tokoh-tokoh humanbeing supranaturalistiknya yang tidak bebas melakukan moving.

Mode ini rupanya menjadi sesuai dengan drama Klasik, termasuk Shakespearean di Barat sebagai drama 'non-realisme sosialistik' yang tidak memerlukan lingkungan dramatika peristiwa lakon. Area permainan hanya sekedar sebagai arena bagi para pelaku tokoh untuk berakting.

Pada drama tradisional yang membawakan cerita fiksi sejarah, mode ini tetap dipakai karena sebagaimana telah disebutkan di depan bahwa unsur-unsur ruang sebagai dekor atau skeneri yang ditampilkan memiliki ikonisitas yang tinggi. Dalam hal ini, dekor sebagai ikon indeksikal memiliki daya pancar eksistensial yang sangat besar. Ruang yang digambarkan secara naratif di dalam naskah cerita sebagai simbol, menjadi lebih bermakna ketika divisualisasikan dengan bentuk unsur-unsurnya. Dengan kata lain visualisasi ruang ini memiliki daya semiotik yang lebih besar daripada kata-kata di dalam naskah cerita.
Drama tradisional yang berlatar kerajaan Kediri misalnya, akan lebih intens memotivasi imaji penonton kepada ruang, waktu dan suasana pada masa kerajaan itu ketika dihadirkan skeneri Candi Bentar yang megah.

Pada drama tradisional cerita sejarah atau fiksi sejarah yang lebih kini, antara dekor dengan pola pengadegan liniernya tidak ada lagi korelasi yang signifikan. Dekor lebih termotivasi oleh gagasan untuk menciptakan latar belakang perspektif. Dengan kedalaman panggung yang terbatas, maka latar belakang perspektif yang meruang dibuat dengan cara ilusif atau perspektif semu. Gagasan ini muncul sebagai salah satu konsekuensi ditemukannya konsep perspektif pada masa Renesans. Dengan demikian bisa disimpulkan bahwa gagasan-gagasan yang muncul dalam upaya untuk memvisualisasikan ruang dan waktu sebagai bagian integral dramatika peristiwa lakon dengan dekor terjadi melalui dua tahap perkembangan yaitu (1) Gagasan menciptakan dekor sebagai tanda ikon indeksikal lingkungan terjadinya peristiwa lakon dan (2) Gagasan menciptakan dekor sebagai ruang perspektif yang memberi wimba realistik sebagai tempat terjadinya peristiwa lakon.

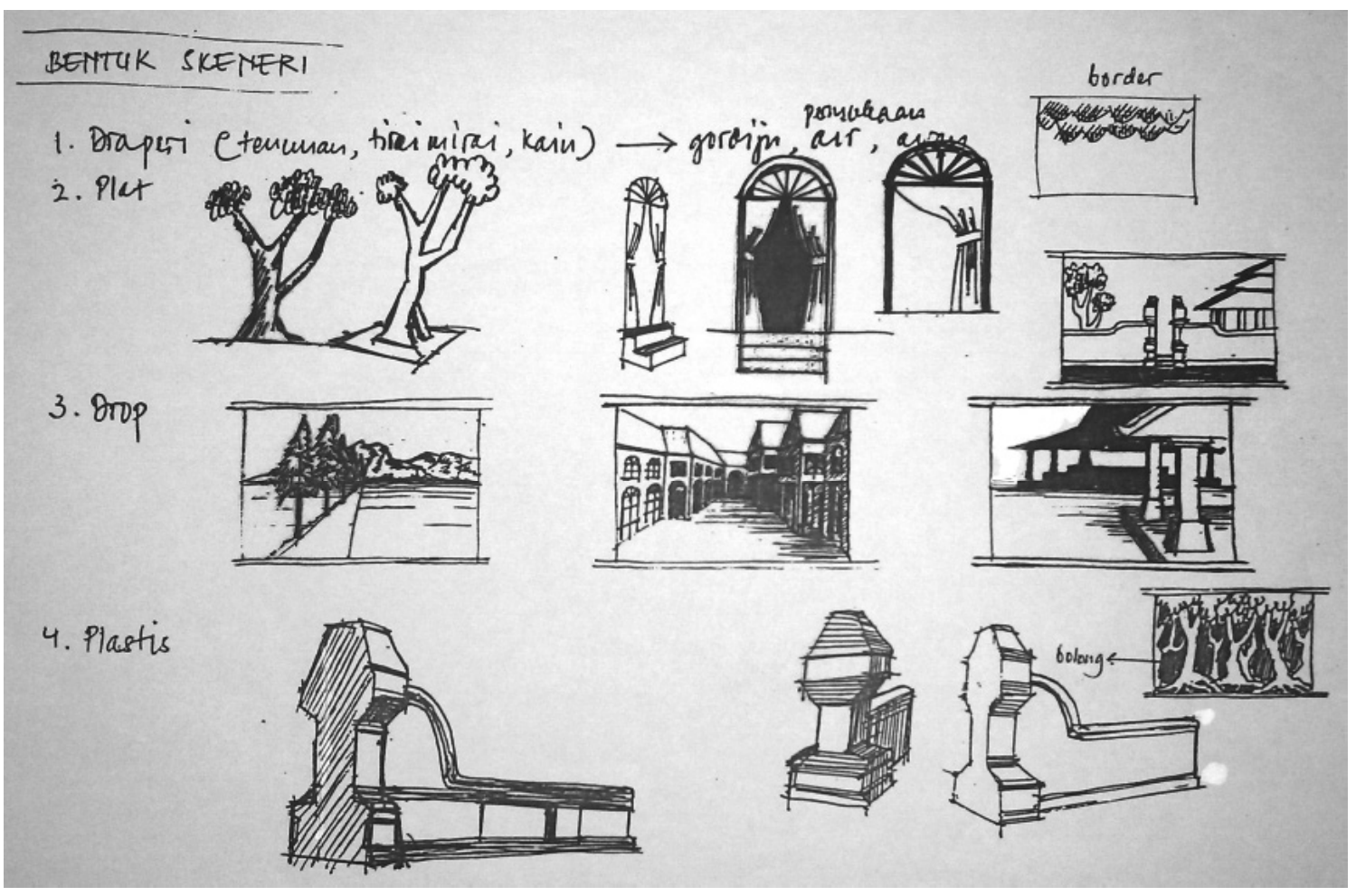

Sketsa unsur-unsur skeneri dekoratif oleh Untung T.B.A. 


\section{Dramatika Tata Panggung Teater}

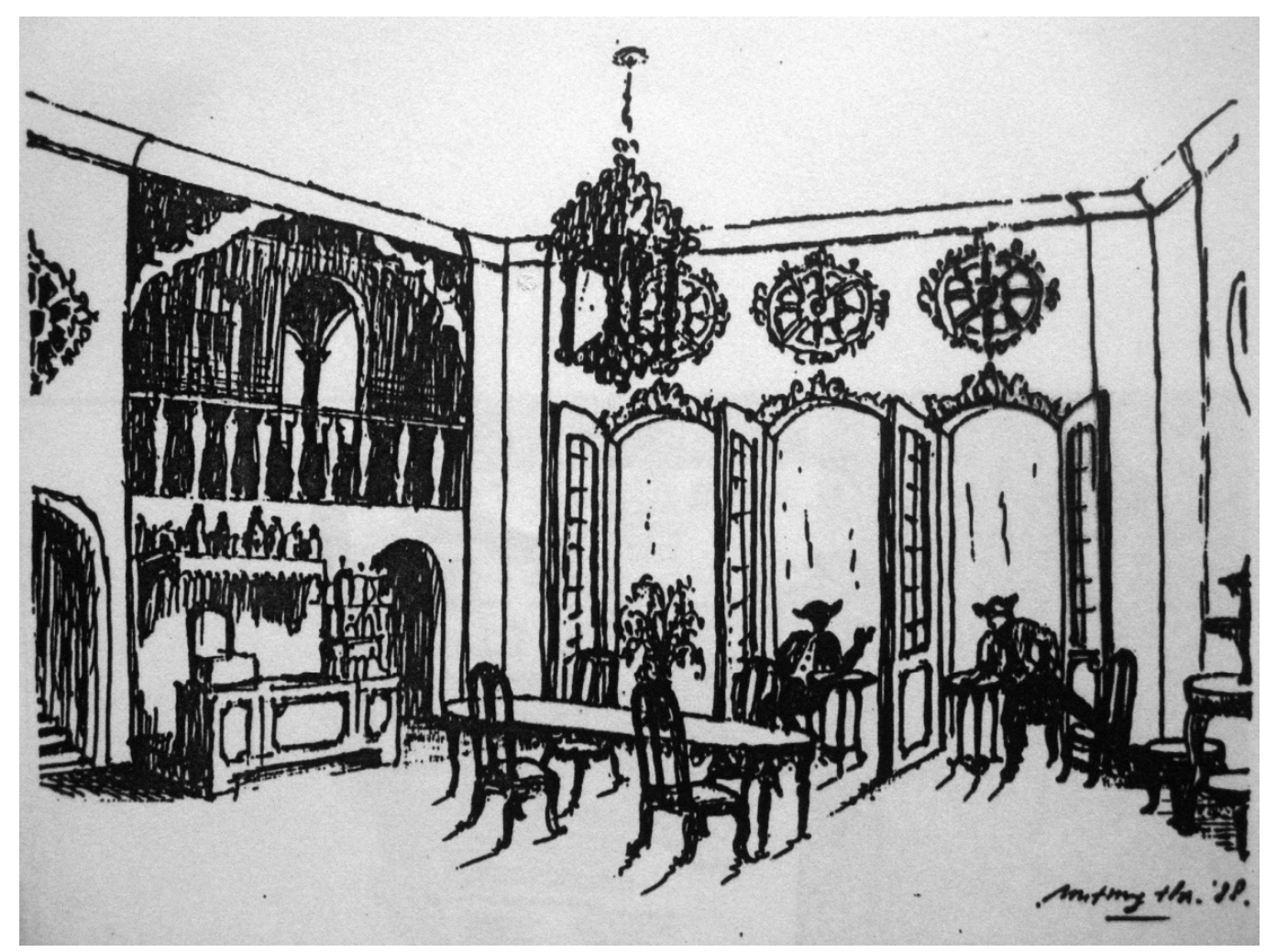

Reproduksi sketsa tata panggung dramatik The Mistress of the Inn Goldoni karya A. N. Benya oleh Untung T.B.A. (Brockett, 1964: 423)

Secara bertahap tata panggung dekor berkembang menjadi tata panggung dramatika mulai abad 18. Tata panggung ini sejalan dengan pola pengadegan yang lebih anguler dan dinamis. Pada tata panggung dramatika, fungsi dekor tetap tidak hilang karena sebagai bagian attraction of spectacle yang tetap penting. Pada tata panggung ini unsur properti semakin banyak melengkapi unsur skeneri. Bisa dikatakan bahwa tata panggung dramatika adalah tata panggung yang lebih menitik-beratkan pada unsur properti daripada skeneri. Sehingga seringkali skeneri digunakan secara minimalis. Hal ini terjadi karena ruang permainan lebih diutamakan daripada latar belakang permainan. Pada tata panggung dramatika, ruang panggung menjadi ruang dramatika, bukan sekedar ruang permainan. Pada tata panggung dekor, hanya pola skene latar belakang yang digunakan untuk mendukung dramatika peristiwa lakon, sedangkan pada tata panggung dramatika, seluruh pola ruang panggung digunakan untuk mengintensifkan dramatika peristiwa lakon.
Drama adalah seni pertunjukan yang ditonton, oleh sebab itu apapun yang menjadi konsep pemanggungannya selalu mempertimbangkan pandangan penonton, meskipun pada awal munculnya panggung prosenium terjadi 'gagap' desain pada tempat duduk auditoriumnya yang masih bergaya Vitruvian. Oleh sebab itu kon_ sep arena dan panggung menjadi konsep cara mempertontonkan apa yang akan ditangkap oleh pandangan penonton.

Arena bukan bagian dari konsep teater rakyat, tetapi lebih bersifat teknis sebagai tempat pertunjukan yang tidak mementingkan skeneri dan bisa ditonton dari berbagai arah pandangan. Embrionya adalah sebidang tanah terbuka di sembarang tempat yang mudah didapat dan mudah dipakai untuk pertunjukan kesenian, akrobat, adu kekuatan dan sebagainya. Konsep kedekatan dengan penonton ditentukan oleh keberadaan tempat pertunjukan lebih dulu, bukan merupakan bagian dari konsep pertunjukannya sejak awal. Tempat pertunjukan yang menjadikan berjarak dekat antara pertunjukan dengan penontonnya, 
dimanfaatkan untuk membuat mode pertunjukan partisipasi, di mana antara pemain dan penonton bisa saling bergantian. Embrionya adalah kelompok-kelompok pesta yang memeriahkannya dengan nyanyian, tarian dan sebagainya. Konsep arena ini menjadi pola dasar pandangan tata panggung dramatika karena seluruh lantai dan ruang menjadi bagian dramatika peristiwa lakon dengan pola pengadegan yang cenderung anguler dan dinamis.

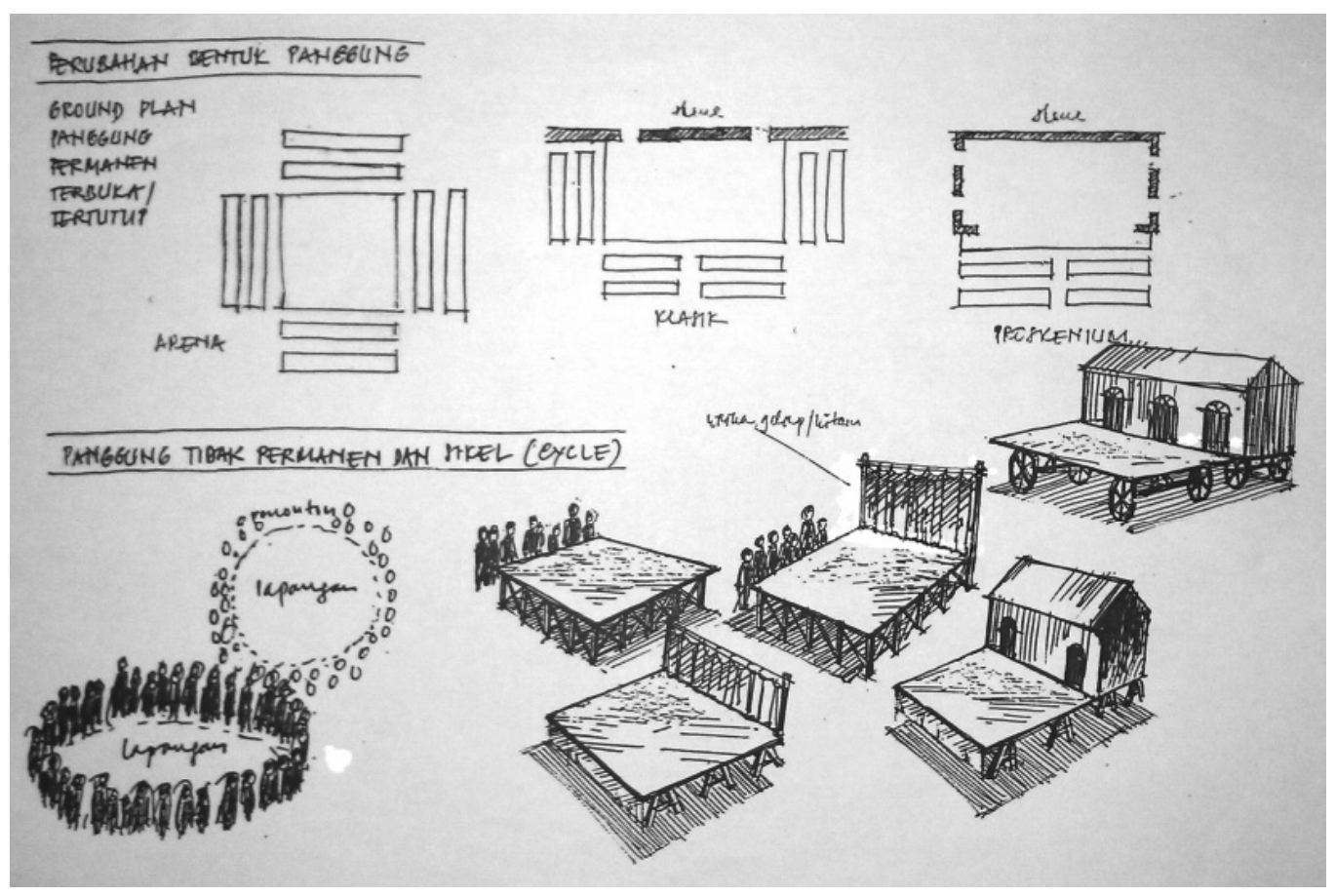

Sketsa perkembangan panggung oleh Untung T.B.A.

Panggung memberi kemungkinan diciptakannya skeneri yang memberi spectacle sensation ruang perspektif yang memotivasi imaji penonton kepada ruang dan waktu tertentu. Di samping itu, panggung juga memberi jarak dengan penonton dan memiliki perangkat untuk menyembunyikan hal-hal yang tidak boleh dilihat penonton. Panggung memberi attraction of spectacle yang terseleksi kepada penonton, sehingga dengan panggung, estetika pertunjukan akan lebih terjaga.

Perpaduan konsep arena dengan konsep panggung identik dengan perpaduan konsep tata panggung dramatika dengan konsep tata panggung dekorasi. Dua konsep inilah sebenarnya yang mendasari konsep tata panggung modern. Gagasan dasarnya adalah menciptakan obyek tontonan yang bisa dipandang secara optimal, estetik dan artistik oleh penonton dengan jarak, arah dan sudut pandangnya.

Sejak masa Renesans, perancangan tata panggung juga menggunakan kaidah-kaidah perancangan yang standar, sebagaimana perancangan pada arsitektur, interior dan sebagainya. Oleh sebab itu para perancangnyapun lebih banyak dari kalangan teknisi, mekanik dan arsitek daripada seniman. Dengan demikian sebuah rancangan yang lengkap meliputi sket dan maket (model) tetap menggunakan sistematika konstruksi proyeksi yang benar dan wajar.

Persoalan yang timbul adalah ketika sket dan maket itu kemudian direalisasikan menjadi set di panggung. Maket tidak bisa dengan serta-merta lalu dibesarkan dengan ukuran yang sesungguhnya di panggung. Sket dan maket adalah rancangan hasil interpretasi ruang yang dideskripsikan dalam naskah, atau bisa disebut sebagai rancangan ruang naskah. Ketika rancangan ruang naskah ditransformasikan menjadi set panggung, maka ada dua faktor yang mengharuskan distorsi yaitu dimensi panggung dan dimensi auditorium atau pandangan penonton.

Dimensi panggung tidak selalu sesuai dengan dimensi rancangan ruang naskah. Lebar dan dalamnya panggung akan menentukan distorsi 
lebar dan dalamnya ruang naskah. Dimensi auditorium yang mempengaruhi pandangan penonton kepada panggung akan menjadi dasar untuk menentukan distorsi skeneri dan properti di latar samping kanan dan kiri. Distorsi ini berupa penataan secara convergent ke belakang tetapi bukan ilusi perspektif. Distorsi ini semata-mata hanya untuk kepentingan pandangan penonton yang berpedoman pada pandangan penonton yang berada di tengah auditorium dengan sudut pandang $60^{\circ}$ ke arah panggung dan refleksinya dari garis tengah silang panggung.

Distorsi pada tata panggung tersebut akan menentukan modifikasi blocking dan moving permainan dari imajinya dalam naskah. Dengan kata lain blocking dan moving imajinatif dalam naskah akan ditransformasikan dalam panggung dengan modifikasi atas dasar kepentingan pandangan penonton. Dengan demikian ada suatu pemahaman bahwa dramatika peristiwa lakon tidak hanya pada permainannya saja, tetapi juga meliputi penataan artistiknya, termasuk penataan panggung.

Distorsi tata panggung tidak hanya sebatas pada kepentingan pandangan penonton, tetapi juga kepada dramatika tata panggung sebagai integralitas dari dramatika peristiwa lakon. Distorsi dramatika tata panggung ini seringkali terabaikan atau tidak disadari oleh penata panggung, sehingga sering terjadi tata panggung hanya sekedar sebagai ruang permainan daripada ruang peristiwa lakon. Distorsi dramatika atau dramatisasi tata panggung ini merupakan stilisasi skeneri dan properti menjadi fenomena skenik dramatika ekspresif dekoratif untuk mendukung attraction of spectacle pertunjukan.

Dalam mendramatisasi tata panggung diperlukan acuan tanda-tanda yang disandangkan pada unsur-unsur tata panggung, meliputi garis, bidang, ruang, bentuk, warna, tekstur dan komposisi. Obyek acuan tanda-tanda ini harus dikenal oleh penonton agar imaji penonton dengan mudah merelasikan antara tanda-tanda pada unsur-unsur tata panggung dengan acuannya. Sebagai contoh, sebuah pintu gerbang kerajaan yang berwarna kusam dan runtuh, akan mencitrakan suatu kerajaan yang sudah surut kejayaannya. Tiangtiang rumah yang miring, mengimajinasikan penghuni rumahnya adalah orang-orang yang bermasalah. Dalam mengeksploitasi penandaan dari banyak obyek acuan ini memang terbatas, namun penandaan pada tata panggung adalah majemuk, dengan demikian akan terjadi sintaksis yang saling menegaskan makna. Di samping itu, tata panggung sebenarnya juga tidak memikul beban sepenuhnya untuk mewujudkan dramatika pertunjukan, tata panggung hanya menegaskan dramatika peristiwa lakon.

Mendramatisasi tata panggung bukan kreativitas yang mudah. Distorsi untuk dramatika dengan deformasi unsur-unsur tata panggung karena kejadian dalam lakon seringkali sulit membuat perbedaan. Pada skeneri kapal yang pecah dihempas ombak ke pantai berbatu karang, deformasinya ada pada bentuk kapal yang pecah. Namun demikian hanya dengan bentuk kapal yang pecah itu saja belum ada dramatikanya.

Dalam penataan panggung pada umumnya masih terpancang pada gagasan untuk menciptakan kesempurnaan bentuk yang realistik dan formal saja sebagaimana penataan dekor. Hal ini sebenarnya yang membatasi ruang terciptanya dramatika tata panggung. Dengan hanya mengambil unsur-unsur representatif ruang yang memiliki ikonisitas tinggi saja akan memberi ruang yang cukup untuk mewimbakan dramatika tata panggung. Dengan demikian dibutuhkan wawasan semiotika yang cukup bagi para penata panggung dalam perancangan tata panggung.

Mentransformasikan ruang, waktu dan suasana sebagai imaji citrawi dalam naskah cerita menjadi tata panggung, pada dasarnya adalah sebuah interpretasi. Penataan panggung yang lebih menekankan pada interpretasi kesempurnaan bentuk yang realistik atau formal akan membatasi dan mengikat imaji penonton terhadap ruang, waktu dan suasana peristiwa lakon. Sedangkan penataan panggung yang lebih merepresentasikan unsur-unsur ruang, waktu dan suasana secara selektif akan lebih memberi kebebasan kepada penonton untuk berimajinasi. Dua mode interpretasi ini biasa dipadukan, tetapi kadang-kadang masih menjadi pilihan. Pada drama tradisional, dalam perkembangannya memadukan dua mode interpretasi ini. Sebuah skeneri pintu gerbang kerajaan dibuat dengan bentuk yang sangat realistik menunjukkan sebagai mode interpretasi yang pertama. Sedangkan penghadiran pintu gerbang itu sendiri menunjukkan mode interpretasi yang kedua karena dipilih atas dasar 
bobot representasinya. Pada drama modern dua mode interpretasi ini seringkali menjadi pilihan. Hal ini terjadi karena lebih ditentukan oleh sifat lakonnya. Pada drama yang bersifat realistikrasional, lebih digunakan mode interpretasi realistik yang banyak memanfaatkan penandaan ikon imajinal-indeksikal. Dramatikanya terletak pada kebentukan skenerinya. Sedangkan pada drama yang bersifat non realistik-fiksional, banyak digunakan mode interpretasi representatif yang lebih memanfaatkan penandaan ikon metaforis-metonimis, kadang-kadang simbolis. Dramatikanya ditampilkan pada distorsi unsurunsur ruang.

Drama realistik-rasional memerlukan skene yang lebih detil dan komplit untuk menampilkan dramatikanya. Sebuah skeneri rumah akan ditampilkan bagian yang diperlukan secara tiga dimensional untuk memotivasi imaji penonton kepada rumah dalam naskah. Dramatika ditampilkan pada kebentukan rumah itu sendiri, kokoh, reyot, modern, kuno, megah, sederhana dan sebagainya. Kebentukan itu merupakan ikon imajinal-indeksikal. Imajinalnya terdapat pada bentuknya yang mencitrakan rumah sesungguhnya. Indeksikalnya tampak pada gaya, kualitas, model, kondisi dan sebagainya yang menunjukkan siapa, bagaimana dan mengapa pemiliknya atau penghuninya.

Skencri drama non realistik-fiksional biasanya merupakan representasi dari ruang metafisika atau supra spasial, berupa unsur-unsur yang membentuk ruang itu. Unsur-unsur ruang dipilih atas pertimbangan derajat ikonisitasnya yang tinggi atau kekuatan semiotiknya yang besar. Skeneri lebih berupa penandaan ikon metaforismetonimis, misalnya tali-temali atau kain yang digantung, berbagai benda non fungsional yang diletakkan, benda-benda fungsional yang ditempatkan secara tidak semestinya dan semua yang terkesan tidak logis, tidak wajar dan tidak mengacu kepada hal-hal yang nyata. Skeneri itu akan memotivasi imaji penonton kepada ruang super realistik, ruang yang hanya ada dalam dunia fantasi. Pada tata panggung yang absurd demikian, dramatikanya dibangun dengan mendistorsi dan mendeformasi skeneri-skenerinya, misalnya tiang dipasang miring, bagian dinding rumah dibuat lapuk bolong-bolong, kursi yang patah kakinya, dinding dicat hitam kelam dan sebagainya sebagai upaya memperkuat dramatika peristiwa lakonnya.

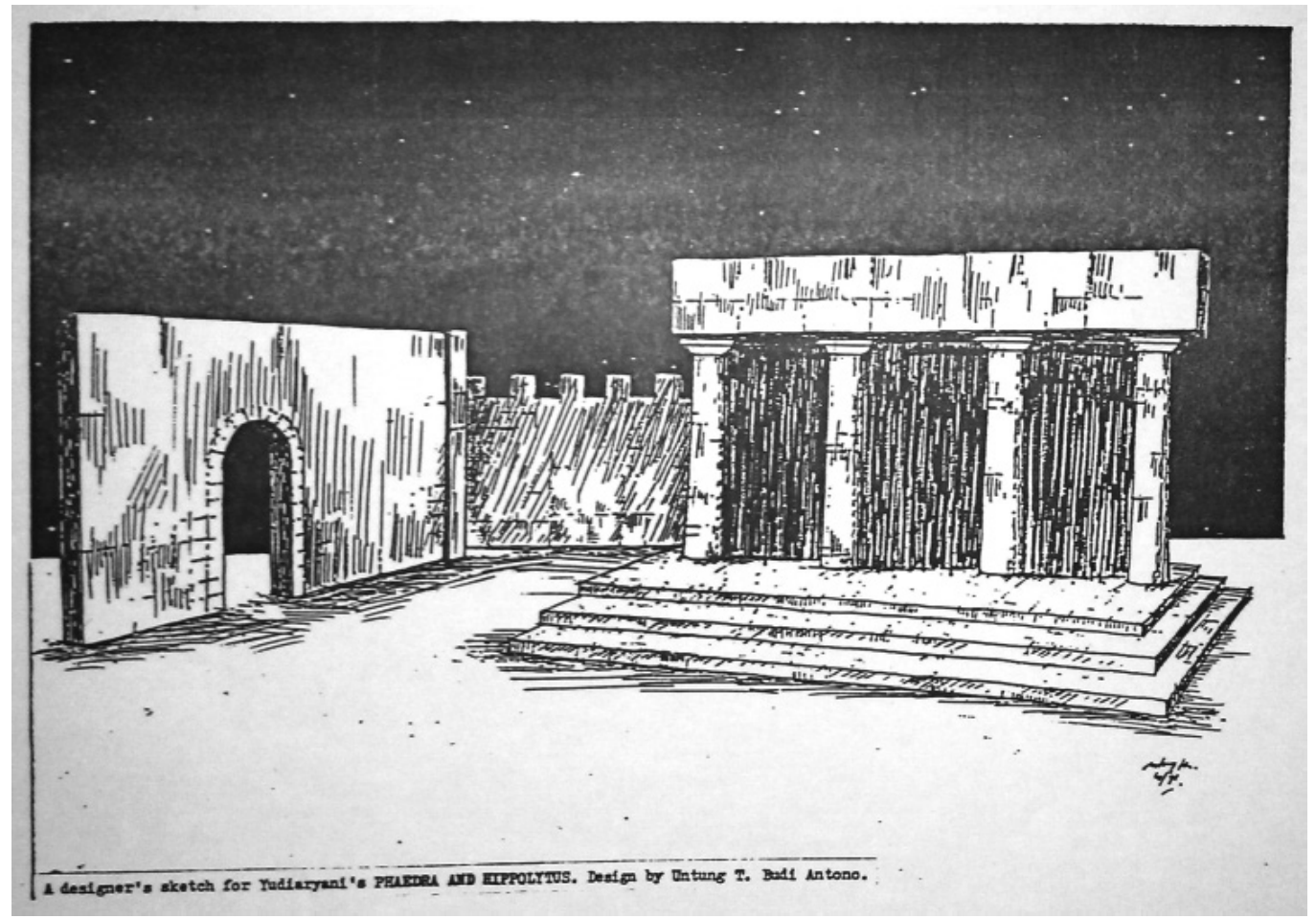

Sketsa tata skeneri dramatik untuk Phaedra and Hippolytus oleh Untung T.B.A. 


\section{Tanda Dramatika Tata Panggung dalam Naskah}

Pada pembahasan ini diambil sampel naskah drama realisme Perhiasan Gelas karya Tennesse Williams dengan judul asli The Glass Menagerie, adaptasi Jim Lim dan Suyatna Anirun. Di dalam naskah tersebut terdapat larik-larik kalimat yang mengandung tanda-tanda yang mengisyaratkan bentuk, ruang, waktu dan suasana yang melatari cerita. Dengan demikian dari larik-larik kalimat tersebut dapat digambarkan bentuk, ruang, waktu dan suasana yang bisa ditransformasikan menjadi tata panggung yang melatari dan mendukung dramatika peristiwa lakon.

Larik-Larik Kalimat dalam Babak 1, Adegan 1, Petunjuk Pentas

Tempat tinggal keluarga Palenkahu di bagian belakang sebuah rumah lama yang didiami dua atau tiga keluarga di salah satu lorong kota lama Jakarta (peninggalan orang-orang Inggris) (1) di daerah kaum menengah kelas dua (2). Pada dinding belakang: dua jendela besar; di mana yang satu dijadikan pintu masuk melalui tangga yang dibuat dan yang satu tertutup (3). Pada dinding kiri dekat jendela masuk: meja kompor dengan keperluan dapur dan sebuah pintu ke kamar Ibu dan Jeane (4). Di muka jendela tertutup: tempat tidur Frits dialingi ampaian (draugtscreen) (5). Pada dinding kanan: meja tulis lemari (rolldesk) dengan foto Sang Ayah di atasnya seperti selalu berkata: Aku akan selalu tersenyum (6). Down-center right: sebuah pouffe buatan sendiri dekat meja tulis, sofa panjang dan sebuah meja rendah di sisi kirinya dengan gramafon corong (7). Down-stage left: sebuah kursi sofa tunggal dan meja rendah di kirinya dengan lampu meja dan tumpukan mainan-mainan binatang dari gelas (8). Center-stage left: meja makan bunder dengan tiga kursi (9). (dst)

Larik Kalimat dalam Monolog 001, Frits

-.----. Ia (tokoh dalam potret) adalah ayah kami yang sudah lama meninggalkan kami. Ia seorang pegawai telpon yang telah jatuh cinta dengan "interlokal", dengan perkataan lain: dunia pengembaraan (10). (dst)
Larik Kalimat dalam Dialog 057, Jeane

Jangan memperlihatkan wajah yang menderita, seperti wajah Ibunda Kristus di gereja Katholik (11). (dst)

Larik Kalimat dalam Babak 2, Adegan 1, Petunjuk Pentas

Ruangan yang sama, Sabtu sore, seminggu kemudian, segalanya tampak rapi, .....-. Beberapa perabotan baru dibeli --.---. Di tempat tidur Frits tampak lampu menyala (12), (dst)

\section{Interpretasi Tanda Tata Panggung Perbi- asan Gelas}

Pada naskah drama realisme ini, petunjuk pentas yang rinci memberikan larik-larik kalimat yang memudahkan interpretasi latar bentuk, ruang, waktu dan suasana peristiwa lakon.

Larik kalimat 1, secara diagramatis bisa diartikan menggambarkan bentuk dan tata ruang abstrak bangunan peninggalan penjajah Belanda. Secara indeksikal hal itu menunjukkan suatu masa pasca kemerdekaan Indonesia ketika kota Jakarta mulai berkembang. Apabila diperkirakan tahunnya, yang cukup logis adalah sekitar tahun 1950.

Larik kalimat 2, secara imajinal menunjukkan status sosial penghuninya, yaitu golongan menengah ke bawah. Secara indeksikal menunjukkan kesederhanaan semua properti dan penataan isi rumah.

Larik kalimat 3, secara diagramatis dan simbolis menggambarkan latar belakang ruang permainan berupa dinding tembok dengan dua jendela besar bergaya bangunan Belanda. Salah satu jendela tertutup, sedang yang lain secara tidak lazim digunakan sebagai pintu masuk dengan menggunakan tangga atau undak-undak. Secara indeksikal hal itu menunjukkan bahwa rumah bangunan Belanda itu tidak memiliki pintu tersendiri untuk akses ke ruang bagian belakang. Dengan demikian ruang permainan bisa diinterpretasikan sebagai ruang keluarga atau multiguna berarsitektural Belanda yang cukup besar, yang satu kesatuan dengan bangunan seluruhnya. 
Larik kalimat 4, secara diagramatis dan simbolis menggambarkan jendela yang digunakan sebagai pintu masuk di dinding latar belakang adalah yang sebelah kiri. Kemudian merapat pada dinding sebelah kiri terdapat meja, di atasnya tertata peralatan dapur, semuanya bergaya tahun 1950an. Lalu di bagian depan dinding itu terdapat sebuah pintu masuk ke kamar.

Larik kalimat 5, secara diagramatis dan simbolis menggambarkan di bawah jendela yang tertutup, di dinding latar belakang, terdapat tempat tidur, merapat ke dinding dan dialing-alingi sekat dari kain, bisa berupa slintru sederhana, semuanya bergaya tahun 1950an.

Larik kalimat 6, secara diagramatis dan simbolis menggambarkan pada dinding sebelah kanan merapat meja tulis yang berfungsi juga sebagai almari beroda bergaya tahun 1950an. Di atas meja almari tersebut menggantung tempel pada dinding foto hitam putih Sang Ayah berukuran sedang berbingkai antik.

Larik kalimat 7, secara diagramatis dan simbolis menggambarkan di tengah panggung pada lantai yang dibuat lebih rendah tertata lima buah properti yaitu: sofa panjang, sebaiknya diletakkan di tengah menghadap ke depan; sebuah meja rendah di sisi kiri sofa dengan gramafon corong di atasnya; sebuah meja tulis, sebaiknya diletakkan di sebelah kanan sofa panjang serong ke kiri dengan sebuah pouffe yang bisa diartikan kursi tanpa sandaran diletakkan di belakangnya. Semua properti tersebut bergaya tahun 1950an. Secara indeksikal gramafon mempertegas masa terjadinya lakon.

Larik kalimat 8, secara diagramatis dan simbolis menggambarkan di bagian kiri panggung, pada lantai yang lebih rendah tertata tiga buah properti yaitu: sebuah kursi sofa tunggal diletakkan menghadap serong ke kanan; sebuah meja rendah di samping kiri kursi sofa tunggal dengan lampu meja dan sekumpulan perhiasan mainan binatang dari gelas di atasnya. Semua properti tersebut bergaya tahun 1950an.

Larik kalimat 9, secara diagramatis dan simbolis menggambarkan di belakang sofa panjang bagian kiri tertata meja makan bundar dengan tiga kursi di kanan, kiri dan belakang seputar meja, juga bergaya tahun 1950an.

Larik kalimat 10, secara indeksikal menunjukkan pekerjaan dan penghasilan kepala keluarga (tokoh Ayah) sebagai pegawai negeri, dengan kesederhanaan penampilan isi dan penataan rumah ketika tokoh Ayah masih hidup, dan mempertegas keadaan lebih sederhana ketika tokoh Ayah sudah mati.

Larik kalimat 11, secara indeksikal menunjukkan agama yang dianut keluarga dalam lakon adalah Kristen Katholik, dan di dalam rumah mereka sebagai tata panggung terdapat simbolsimbol agama tersebut, yaitu salib, patung Maria dan potret Yesus, minimal salib. Namun demikian kehadiran simbol-simbol agama tersebut tidak harus ada apabila tidak berkaitan dengan cerita.

Larik kalimat 12, secara imajinal mencitrakan keadaan ruang yang lebih tertata rapi daripada babak sebelumnya. Di samping ada sedikit perubahan penataan properti, misal letak kursi yang lebih formil, juga ada beberapa properti yang diganti baru dan meja kecil untuk meletakkan lampu meja yang menyala di dekat tempat tidur di bawah jendela yang tertutup. Meja kecil dan lampu meja tersebut bisa dihadirkan sejak awal.

\section{Reduksi Tata Panggung Perhiasan Gelas}

Untuk menghindari dominasi penampilan tata panggung yang bisa mengaburkan permainan di depannya, serta agar praktis dalam penataannya, tembok atau sebagian tembok bisa dibuat imajiner. Dengan demikian dinding lebih diwakili dengan bingkai-bingkai jendela dan pintu yang digantung atau didirikan dengan penopang pada kakinya. 


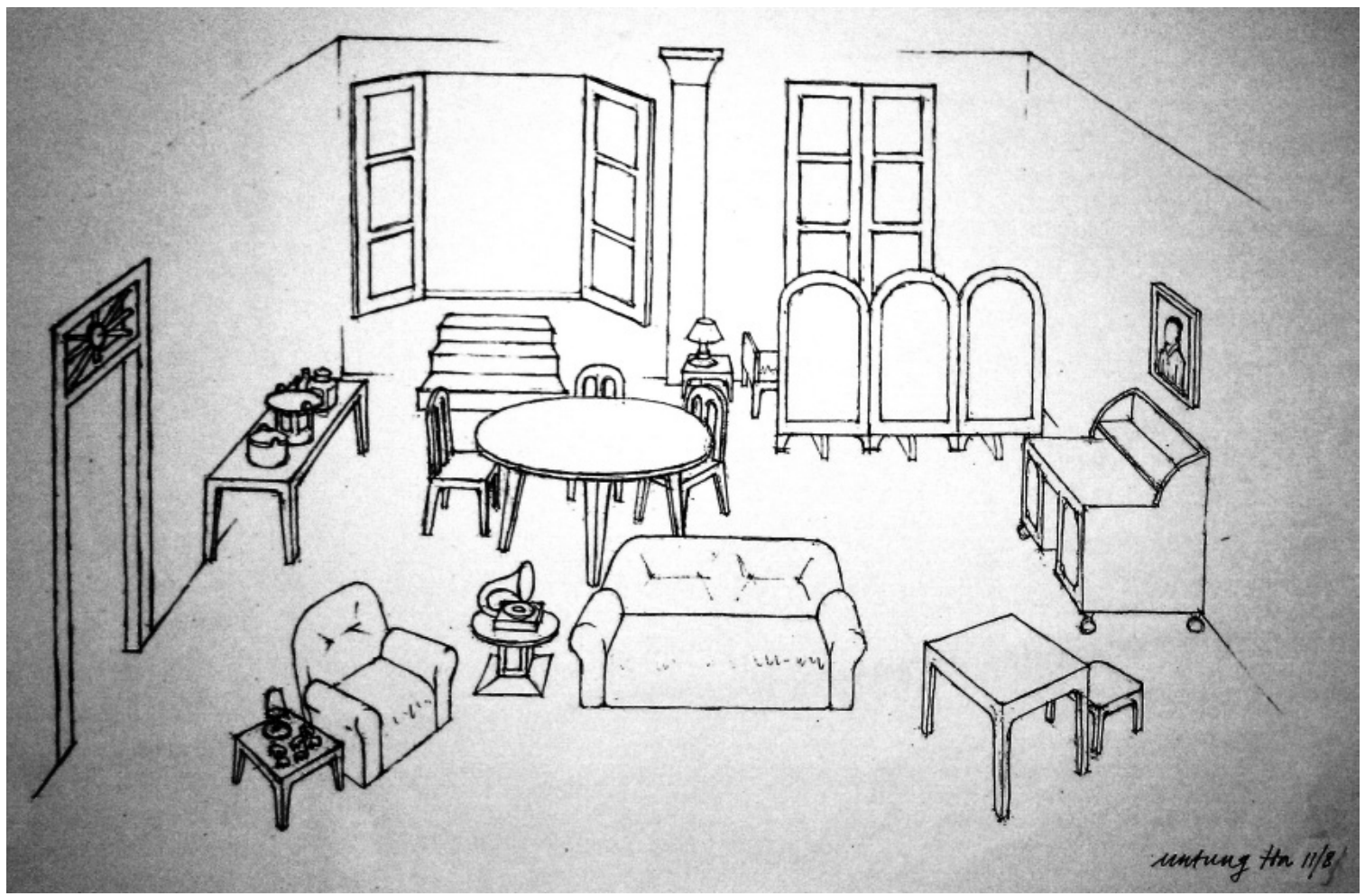

Sketsa pola tata panggung alternatif Perhiasan Gelas oleh Untung T.B.A.

\section{Penutup}

Tata panggung bukan sekedar unsur ruang dan waktu peristiwa lakon dalam pementasan drama. Dalam fungsinya sebagai dekor dan pendukung dramatika, tata panggung adalah kesatuan tanda yang mengacu pada designata citrawi atau obyek konkrit yang tidak kasat mata dalam naskah. Dengan demikian tata panggung sebagai wimba, akan mengarahkan dan mengikat imaji penonton kepada suasana yang setidaknya akan mendekati yang dicitrakan oleh penulis atau pengarang ceritanya. Tata panggung merefleksikan sikap manusia terhadap ruang secara fisik maupun psikis sebagai pengalaman ruang yang menentukan kualitas peristiwa lakon.

\section{Kepustakaan}

Antono, Untung Tri Budi. 2000. "Proses Pembentukan Teater Prosenium", dalam Tonil, Volume 1, Nomer. 1. 2004. "Proses Perkembangan Panggung Teater Klasik", dalam EKSPRESI, Volume 12, Tahun 4.
2007. "Pasang Surut Perkembangan Tata Teknik Pentas Kesenian Ketoprak", dalam Tonil, Volume 3, Nomer 3.

Brockett, Oscar G.. 1964. The Theatre an Introduction. London: Holt, Rinehart.

1988. The Essential Theatre. London: Holt, Rinehart.

Budiman, Kris. 2005. Ikonisitas, Semiotika Sastra dan Seni Visual. Yogyakarta: Buku Baik.

Cameron, Kenneth M.; Hoffman, Theodore J.C. 1971. The Theatrical Response. London: The Macmillan Company.

Christiawan, Wawan. 1992. "Konsep Skenografi Rancangan Roedjito sebuah Tinjauan Deskriptif Skenografi pada Tiga Pementasan Drama Modern di Taman Ismail Marzuki Jakarta 1984-1991", [Skripsi] Jurusan Teater, Fakultas Kesenian, ISI Yogyakarta.

Cohen, Robert. 1983. Theatre Brief Edition. Palo Alto: Mayfield Publishing Company.

Eco, Umberto. 1976. A Theory Semiotics. Bloomington: Indiana University Press. 
Kernodle, George R.. 1967. Invitation to the Theatre. Atlanta: Harcourt.

Macgowan, Kenneth; Melnitz, William. 1965. The Living Stage, A History of the World Theater. New Jersey: Prentice-Hall.

Nöth, Winfried. 1990. Handbook of Semiotics. Indianapolis: Indiana University Press.

Ommanney, Katharine Anne. 1960. The Stage and The School. London: Mc Graw-Hill Book Company, Inc.
Padmodarmaya, Pramana. 1983. Tata dan Teknik Pentas. Jakarta: Depdikbud.

Roberts, Vera Mowry. 1962. On Stage, A History of Theatre. London: Harper \& Row publishers.

Whiting, Frank M.. 1969. An Introduction to the Theatre. London: Frank M. Whiting. 